\title{
The Effect of Diboracy (Digital Book Containing Scientific Literacy) in Reducing Misconceptions on Newton's Law of Gravity
}

\author{
*Fauzia Dwi Sasmita, Muhammad Arifuddin, Saiyidah Mahtari \\ Physics Education Department, FKIP Universitas Lambung Mangkurat, Jl. Brigjen H. Hasan \\ Basri, Banjarmasin 70123, Indonesia \\ *Corresponding Author e-mail: fauziadwi11@gmail.com \\ Received: November 2020; Revised: November 2020; Published: December 2020
}

\begin{abstract}
The low utilization of technology and scientific literacy skills lacking in the classrooms remain a major problem in the learning and teaching process, specifically in influencing students' conceptual understanding. This research aims to analyze the effect of Diboracy (Digital Book Contained Scientific Literacy) in reducing misconceptions in Newton's law of gravity. This research uses experimental research design with one group pretest-post-test conducted on research subjects which were selected through random sampling technique. The sum of the research subjects include 38 students. The data instruments include tests and non-tests instruments. The test distributed is in the form of multiple choice questions equipped with CRI to measure the misconceptions, while the non-test assessment takes form of questionnaires to determine students' responses to Diboracy. Data analysis was performed through t-test on student learning outcomes and the students' questionnaire responses which resulted in the average percentages. Based on the analysis, it can be concluded that: (1) there is an effect in reducing students' misconceptions when Diboracy is implemented, specifically regarding Newton's law of gravity; (2) students give better responses to Diboracy than textbooks.
\end{abstract}

Keywords: diboracy; misconception; newton's gravity

How to Cite: Sasmita, F., D., Arifuddin, M., \& Mahtari, S. (2020). The Effect of Diboracy (Digital Book Containing Scientific Literacy) in Reducing Misconceptions on Newton's Law of Gravity. Prisma Sains: Jurnal Pengkajian Ilmu dan Pembelajaran Matematika dan IPA IKIP Mataram, 8(2), 112-121. doi:https://doi.org/10.33394/j-ps.v8i2.3164

\section{INTRODUCTION}

The development of technology in the 21 st century has changed the paradigm of education which has been focusing on teaching to learning (Afandi, Junanto, and Afriani, 2016). The implementation of education which is adaptive to technological developments also encourages every human being to have the skills to be able to compete in various sectors of life. One of the skills referred to is scientific literacy skills (Nofiana and Julianto, 2018). Science and technology are the most prominent characteristics needed in the modern world, and thus, scientific literacy is a requirement that must be possessed by every individual (Vieira, Melo, Avraamidou and Lobato, 2017), especially students. Students are required to master literacy to understand laws, theories, and phenomena, as well as to comprehend the basis of scientific knowledge needed to make decisions (Dragoş and Mih, 2015).

However, Indonesia's participation in PISA (Program for International Student Assessment), which has been conducted for more than a decade, still places the scientific competence of Indonesian students in the low category. In 2018, Indonesia was ranked 62 out of 71 countries with the average score of students in the science field below the OECD (Organization for Economic Cooperation and Development) average score, which is 396 out of 489. Weak scientific competence results in weak understanding of science concepts 
(OECD, 2019), which tends to cause misconceptions or misunderstandings of the science concepts (Aulia, Diana, and Yuberti, 2018).

Misconception is an initial concept as a result of knowledge construction that is not in accordance with scientific concepts (Alhinduan, Kurniawan, and Muliyani, 2016; Suparno, 2013). Physics, as a branch of science that emphasizes mastery of concepts for intellectual abilities (Saputri \& Nurussaniah, 2015), in fact, tends to contain misconceptions in all areas of study (Wandersee, Mintez, and Novak, 1994), such as in the material of Earth and Space Sciences (Fauzia and Madlazim, 2015), Regular Circular Motion (Annisa, Astuti, and Mindyarto, 2019), Newton's Law (Zulvita, Halim, and Kasli, 2017), Heat Temperature (Zayyinah, Munawaroh, and Rosidi, 2018), and Energy Effort (Maison, Lestari, and Widaningtyas, 2020). The factors causing high level of misconceptions in the field of physics studies include the cognitive abilities of students, the teacher's ability and mastery of material, the context of learning, teaching methods and textbooks (Suparno, 2013).

Out of the five causes of these misconceptions, Simanek (2016) stated that didacticogenic misunderstanding (internal misunderstanding due to the learning system) caused by textbooks is the main cause of misconceptions. The use of textbooks as a cause of misconceptions in physics lessons can be caused by the language used in presenting material such as in translated textbooks (Zajkov, Zajkova, and Mitrevski, 2016). The main source of textbooks that cause misconceptions can also come from unclear illustrations or inappropriate use of images (Gurel, Eryilmaz, and Dermott, 2015), which may affects students' conceptual understanding.

Efforts to reduce misconceptions in the topics of physics have been carried out by many researchers, including by applying various learning models (Kesuma, Diani, Hasanah, and Fujiani, 2020; Rosuli, Koto, and Rohadi, 2019), different approaches in teaching the students (Parwati, Makhrus, and Gunada, 2019) ), as well as approaches to teachers (Ilyas and Saeed, 2018; Kurniawan and Maryanti, 2018). Even the use of technology as an effort to reduce misconceptions in physics material has also been carried out (Hidayatulloh, Wiryokusumo, and Walujo, 2019; Kurniawan, Muliyani, and Nassim, 2019; Ozkan and Selcuk, 2015). However, so far, there has not been much research in efforts made to reduce misconceptions through scientific literacy, especially on Newton's law of gravity. In fact, Neidorf, Arora, Erberber, Tsokodayi, and Mai (2020) stated that the misconceptions experienced by students were mostly related to the topic of gravity. Additionally, Syuhendri (2019) states that knowledge and concepts found on the topic of gravity often lead to misconceptions. Therefore, this research was carried out by combining technological advances through the use of Diboracy in reducing students' misconceptions in Newton's law of gravity. This study aims to describe the effect of Diboracy in reducing misconceptions in Newton's law of gravity.

\section{METHOD}

This research utilized an experimental research design with a pre-experimental one group pre-test and post-test design. Through random sampling technique, 38 students of Grade X Science 7 students of a senior high school in Banjarmasin were selected as the research subjects. Diboracy was implemented on the topic of Newton's law of gravity with three study sessions covering 4 indicators: (1) analyzing the gravitational force between two objects using Newton's Law of Gravity equation based on indicators of conceptual knowledge in scientific literacy; (2) analyzing the gravitational acceleration between the two planets based on conceptual knowledge indicators on scientific literacy; (3) analyzing the orbital speed of the satellite based on conceptual knowledge indicators on scientific literacy; and (4) analyzing the period of planetary revolution based on indicators of facts and/ knowledge of concepts on scientific literacy.

The type of the data collected in this study are quantitative data and qualitative data with the data collection instruments include tests and non-test instruments. Quantitative data 
were obtained from the learning outcomes test (LOT) of students prior (pre-test) and after (post-test) using Diboracy, in the form of 10 multiple choice question items equipped with CRI (Certainty of Response Index) with a confidence level scale from 0-5 (Table 1). Meanwhile, the qualitative data were obtained from non-test instruments in the form of questionnaires containing 25 statement items with five indicators: (1) students' enthusiasm in learning; (2) comprehensibility of the material; (3) material substance; (4) convenience in obtaining information; (5) use of visual media/illustrations is as needed. The data from the pre-test and post-test results were then analyzed to determine the percentage of the criteria of students who understood the concepts, those who had misconceptions, and those who did not understand the concepts. Meanwhile, the questionnaire result data was used to explore the students' responses on the implementation of Diboracy.

Table 1. The Criteria of Concept Understanding Based on the CRI Index (Hasan, Bagayoko, \& Kelley, 1999)

\begin{tabular}{lll}
\hline Criteria & Low CRI $(<\mathbf{2 . 5})$ & High CRI (> 2.5) \\
\hline Correct answer & $\begin{array}{l}\text { Correct answer and the CRI is low; } \\
\text { did not understand the concept } \\
\text { (lucky guess) } \\
\text { Incorrect answer and the CRI is low; } \\
\text { did not understand the concept }\end{array}$ & $\begin{array}{l}\text { Correct answer and the CRI is high, } \\
\text { understands the concept well }\end{array}$ \\
$\begin{array}{l}\text { Incorrect answer and the CRI is high; } \\
\text { misconception }\end{array}$ \\
\hline
\end{tabular}

The qualitative data in this study were obtained from a response questionnaire prior and after the implementation of Diboracy. The use of response questionnaires aims to explore students' responses on the use of Diboracy in reducing misconceptions.

Table 2. The Criteria of Responses on Textbooks and Diboracy (Adapted from Akbar, 2016)

\begin{tabular}{ccll}
\hline No & Average Score (\%) & Category \\
\hline 1 & $80.01-100.00$ & Excellent & Well \\
2 & $60.01-80.00$ & Quite well \\
3 & $40.01-6.00$ & Poor \\
4 & $20.01-40.00$ & Very Poor \\
5 & $0.00-20.00$ & \\
\hline
\end{tabular}

Based on the $r$ table and the moment product reliability value, the instrument is declared valid if it gets a minimum score of 0.31 . Moreover, it is also declared reliable if it gets a minimum score of 0.60 . The validity and reliability of the instruments used in this study are presented in Table 3.

Table 3. The Validity and Realibility of the Instruments

\begin{tabular}{cccc}
\hline Instruments & Validity & Reliability & Category \\
\hline LOT & 0.53 & 0.60 & Valid and Reliable \\
Survey Responses & 0.54 & 0.88 & Valid and Reliable \\
\hline
\end{tabular}

The normality test in this study utilized the Shapiro-Wilk test. The data is assumed to be normally distributed if the Asiymp value. Sig (2-tailed) is greater than 0.05. Meanwhile, to determine the effect of Diboracy in reducing misconceptions, a t-test was carried out through the criteria of significance level $(\alpha)=0.05$ or $5 \%$ with the following conditions: (1) Ho is accepted if Sig $>0.05$, or $\mathrm{t}$ count $\leq \mathrm{t}$ table; and (2) Ho is rejected if $\mathrm{Sig}<0.05$, or $\mathrm{t}$ coun $\mathrm{t}\rangle \mathrm{t}$ table. The statistical hypothesis tested in this study is (1) H0: There is no effect on the implementation of Diboracy in reducing misconceptions about Newton's law of gravity; and (2) Ha: There is an effect on the implementation of Diboracy in reducing misconceptions in Newton's law about gravity.

\section{RESULTS AND DISCUSSION}

Table 4 illustrates the number of students based on the conceptual understanding criteria during the pre-test and post-test. Meanwhile, Table 5 presents the percentage of students' 
conceptual understanding as a whole, which is then divided into understanding concepts, not understanding concepts, and had misconceptions before and after using Diboracy.

Table 4. Number of Students Based on Criteria for Understanding the Concept of Each Question Item Before (Pre-test) and After (Post-test)

\begin{tabular}{cccccccc}
\hline \multirow{2}{*}{ Indicator } & \multirow{2}{*}{ Question no. } & \multicolumn{3}{c}{ Pre-test } & \multicolumn{3}{c}{ Post-test } \\
\cline { 3 - 7 } & & $\mathbf{U}$ & $\mathbf{N U}$ & $\mathbf{M C}$ & $\mathbf{U}$ & $\mathbf{N C}$ & MA \\
\hline \multirow{2}{*}{1} & 1 & 17 & 11 & 10 & 34 & 1 & 3 \\
& 2 & 2 & 15 & 21 & 27 & 2 & 9 \\
2 & 3 & 4 & 16 & 18 & 30 & 3 & 5 \\
\multirow{3}{*}{3} & 4 & 4 & 15 & 19 & 21 & 5 & 12 \\
& 5 & 5 & 15 & 18 & 31 & 2 & 5 \\
& 6 & 15 & 8 & 15 & 35 & 2 & 1 \\
4 & 7 & 0 & 13 & 25 & 5 & 6 & 27 \\
& 8 & 0 & 18 & 20 & 17 & 2 & 19 \\
& 9 & 9 & 11 & 18 & 23 & 3 & 12 \\
& 10 & 0 & 19 & 19 & 21 & 2 & 15 \\
\hline
\end{tabular}

Note $=$ U: Understood;

NU: Not understood;

MC: Misconception

Table 5. The Percentage of Cognitive Achievement Prior and After Taught Using Diboracy

Level of Comprehension

Understood

Not Understood

Misconcept

Based on Table 5, it was known that there was an increase in students' conceptual understanding, which was $49.48 \%$ after using Diboracy. The increase in students' understanding of this concept was accompanied by a decrease in the percentage of students who experienced misconceptions and did not understand the concept, respectively, namely $29.74 \%$ and $18.74 \%$. For more detail, the cognitive achievements of students on each indicator which include misconceptions, not understanding concepts, and understanding concepts are shown in Figure 1.

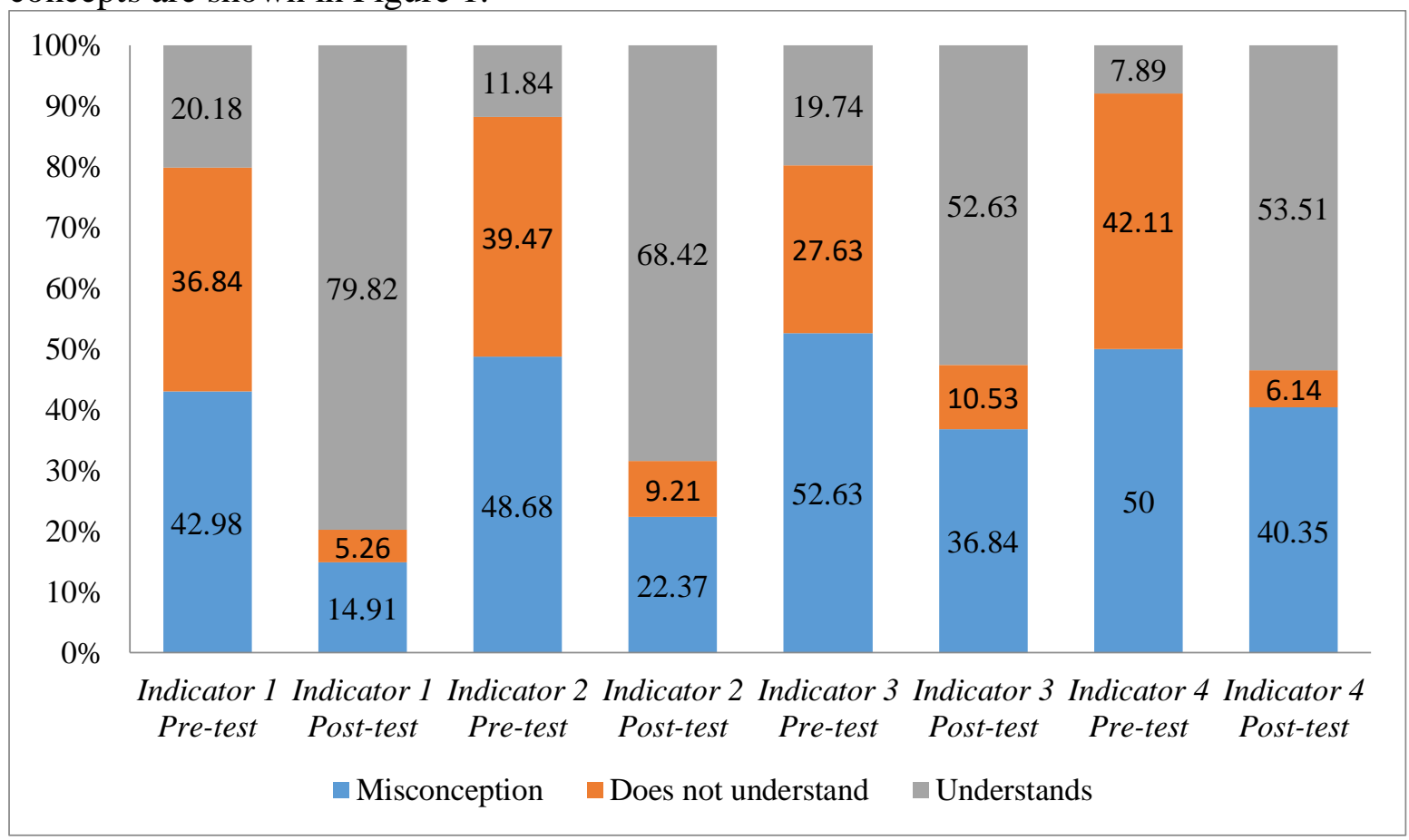

Figure 1. The Percentage of Students' Conceptual Understanding Scores per indicator before (pre-test) and after (post-test) using Diboracy is showed above 
Based on the normality test that has been carried out, the data obtained is shown in Table 6.

Table 6. The Data Results of the Normality Pre-test Post-test

\begin{tabular}{cc}
\hline Data & Significance \\
\hline Pre-test & 0.085 \\
Post-test & 0.697 \\
\hline
\end{tabular}

Since the significance value obtained was greater than 0.05 , the two data are normally distributed. Next, the paired t-test was carried out to determine whether or not the influence of Diboracy was present in reducing students' misconceptions. The pre-test and post-test of the students' tests are presented in Table 7 below.

Table 7. The Analysis of the T-Test Results

\begin{tabular}{ccccc}
\hline Pre-test & Average Post-test Score & t-test & t table & Significance \\
\hline 9.78 & 61.30 & 19.804 & 1.68709 & 0.00 \\
\hline
\end{tabular}

The Table 7 showed that the acquisition of $t$ count, which was greater than $t$ table, was reinforced by the significance of 2 parties which are smaller than 0.05 . The hypothesis regarding the influence of Diboracy in reducing misconceptions in Newton's law of gravity is thus acceptable. The decreased level of misconception and the increased achievement of students' conceptual understanding on the pret-test and post-testss were then analyzed by comparing the results of students' responses to the use of textbooks and Diboracy.

Table 8. Comparison on Students' Responses towards Textbooks and Diboracy

\begin{tabular}{clcc}
\hline No & \multicolumn{1}{c}{ Responses Indicators } & Textbooks (\%) & Diboracy (\%) \\
\hline 1 & Enthusiasm in learning & 33 & 82 \\
2 & Easeness in comprehending the Materials & 38 & 97 \\
3 & Material substances & 38 & 74 \\
4 & Easemess & 62 & 92 \\
5 & Use of visual media or intro sentic as needed & 44 & 87 \\
\hline \multicolumn{2}{r}{ Average } & $\mathbf{4 3}$ & $\mathbf{7 0 , 4}$ \\
\hline & Category & Quite Good & Good \\
\hline
\end{tabular}

Based on the data in Table 8 , it is confirmed that there is an increase in students' enthusiasm for learning into $82 \%$. This increase was supported due to the ease felt by students in understanding the material of Newton's Law of Gravity. One of the factors reviewed is the use of foreign terms such as, "Let's See", "Let's Try", and "Let's Fight", which have been commonly heard and used by students. In addition, vocabularies such as Goldilocks, Retrograde, and Light Years related to Newton's Law of Gravity have been adapted to the cognitive abilities of learners. Typographic aspects include typeface (Dogusoy, Cicek, and Cagiltay, 2016), font size (Franken, Podlesek, and Mozina, 2015), spacing (Hojjati and Muniandy, 2014), and color and background (Anuardi, Shinohara, and Yamazaki, 2016) is also a supporting factor that makes it easier for students to understand the material.

Diboracy uses two fonts in the Sans Serif category, namely Calibri (body) and Just Another Hand, which had a significant impact on the aspect of readability (ease of reading and understanding of text) (Hojjati and Muniandy, 2014), and thus, it is appropriate to use on text displayed on a computer screen (Moret-Tatay and Perea, 2011). Sans Serif group fonts also help students to read text more quickly and accurately (Dogusoy et al., 2016). Judging by the size of the letter, in general, Diboracy uses the font size 14. This is in line with a research conducted by Banerjee and Bhattacharyya (2011) which stated that students can read faster at font size 14. Diboracy also uses double spacing in order to ease students to read the text more carefully, and make it easier for students to recognize and start each sentence (Hughes and Wilkins, 2002). Therefore, the use of double spaces is highly recommended (BlackmoreWright, Georgeson, and Anderson, 2013; Hojjati and Muniandy, 2014). The layout on Diboracy is dominated by lazuardi (sky blue color), which plays a role in stimulating and 
improving students' cognitive understanding (Xia, Song, Wang, Tan, and Mo, 2016)) with a white background which also has a positive impact on readability (Keček, Zorko, Čerepinko, Tomiša, and Valenko, 2017).

The substance of the material in Diboracy refers to the learning objectives that have been planned and presented in a systematic manner and is equipped with discussion activities at the end of each sub-material. Diboracy contains indicators of scientific literacy which include science as a body of knowledge, science as a way of investigating, science as a way of thinking, and interactions between science, technology and society (interaction of science, technology, and society).

\section{A hukumgravitasinewton.online $\uparrow^{\uparrow}$}

\section{MEDAN GRAVITASI}

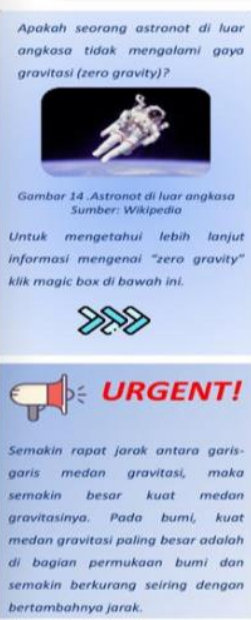

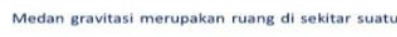

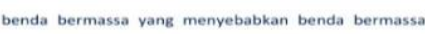

lainnya yang ada di sekitar ruang tersebut mengalam gaya gravitasi.
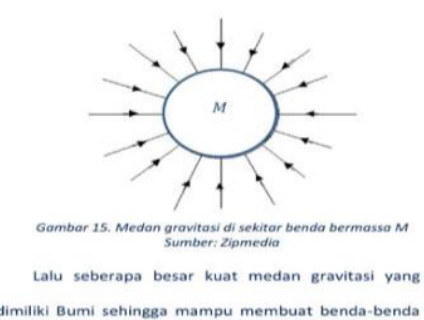

gravitasi g dinyatakan sebagai:
)

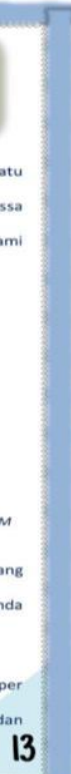

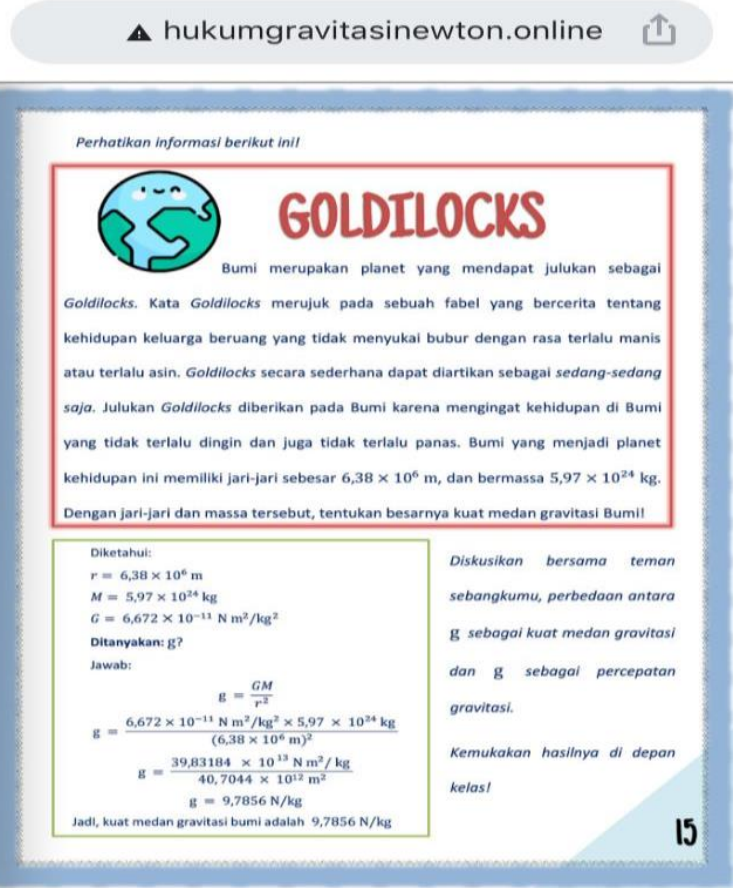

Figure 2. Science as a body of knowledge Figure 3. Science as a way of (presenting a concept) investigating (thinking activity)

A hukumgravitasinewton.online t]

\section{SATU TAHUN ADA BERAPA HARI?}

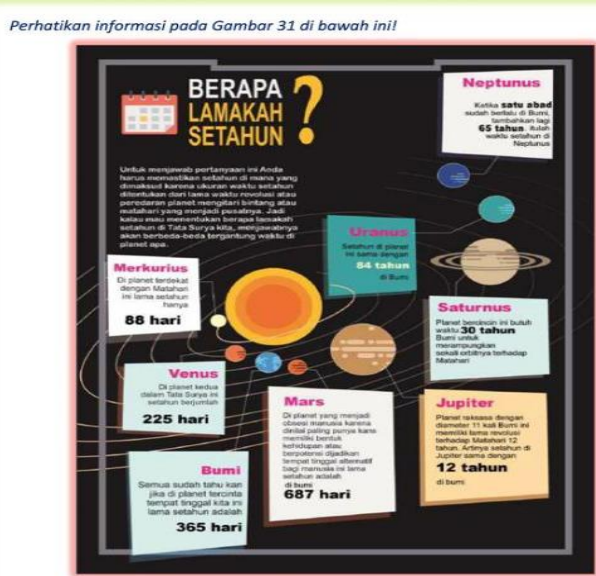

29 and-effect situations)

Figure 4. Science as a way of thinking (cause- Figure 5. Interactions of science with

\section{SAMPAH ANTARIKSA}

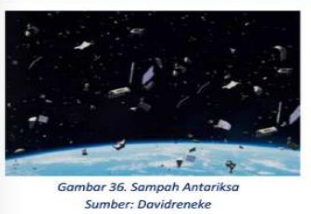

Kemajuan IPTEK telah memicu semangat

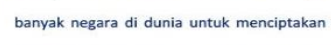

kemudahan dalam aspek kehidupan. Salah

satu upayanya ialah dengan meluncurkan satelit (cuaca, komunikasi, navigasi, militer).

Tabel 2. Negara Pemilik Satelit Terbanyak

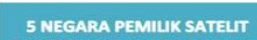

5 NEGARA PEMMUIK SATEUT

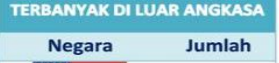

Negara

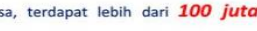

sampah antariksa. Sampah tersebut

didominasi oleh puing-puing roket maupun

satelit buatan yang telah habis masa

aktifnya dan tidak befungsi tagi. sampat

antariksa menyebabkan potensi bahaya bagi kehidupan di Bumi, seperti tabrakan dengan

satelit buatan yang masih aktif maupun dengan stasiun luar angkasa seperti Iss technology, and society 
The content of scientific literacy in Diboracy enriches knowledge and information on the topic of Newton's law of gravity, which resulted in broadening and deepening the students' concept of scientific understanding (Fananta et al., 2017). This is in line with several studies Yunita and Nana (2020); Tarmizi, Halim, and Khaldun (2017) which state that increasing students' conceptual understanding will reduce student misconceptions.

The aspect of the convenience of finding information has also increased. Information given through the Literacy Corner feature and the Tau Gak, sih? column presents scientific figures and the history of the birth of Heliocentric theory as well as the background in the formulation of Kepler's Law. Diboracy also presents job prospects in the field of Astronomy and the current impact of the rapid development of science and technology. This information is important to know as it is able to stimulate students' curiosity, increase enthusiasm for learning, and help understand physics concepts, so as to reduce misconceptions and have a positive impact on student academic achievement (Aina, 2013; Berman and Kuden, 2017; Shin, Lee, and Ha, 2017). In addition, Diboracy also reduces the role of text and prioritizes the use of visual media such as illustrations for planets, animations of rotational movements and revolutions of celestial bodies, to videos related to physics equations and the history of science. The use of visual media aims to make it easier for students to process information (Sharif, Wills, and Sargent, 2010; Vijaya, 2018) and help reduce misconceptions (Samsudin, Liliawati, Sutrisn, Suhendi, and Kaniawati, 2014).

\section{CONCLUSION}

Based on the analysis and discussion elaborated above, it is concluded that: (1) there is an effect caused by teaching using Diboracy in reducing student misconceptions, especially regarding Newton's law of gravity; (2) students give better responses to the use of Diboracy than textbooks.

\section{RECOMMENDATION}

The results of this study have implications for reducing misconceptions in physics lessons, especially on Newton's law of gravity. It is hoped that similar research will be carried out by carrying out scientific literacy integrated contents in the learning process combined with technology as an effort to reduce misconceptions in other physics materials

\section{ACKNOWLEDGEMENT}

This research received no specific grant from any funding agency in the public,commercial, or not-for-profit sectors.

\section{REFERENCES}

Afandi, A. (2016). Implementasi Digital-Age Literacy dalam Pendidikan Abad 21 di Indonesia. Developing High Order Thinking Stimulation Model for Pre-Service Teachers' Science Education View project. Prosiding Seminar Nasional Pendidikan Sains "Peningkatan Kualitas Pembelajaran Sains Dan Kompetensi Guru Melalui Penelitian \& Pengembangan Dalam Menghadapi Tantangan Abad-21", February, 113-120. https://www.researchgate.net/publication/313064817

Aina, J. K. (2013). Effective Teaching and Learning in Science Education through Information and Communication Technology [ICT]. IOSR Journal of Research \& Method in Education (IOSRJRME), 2(5), 43-47. https://doi.org/10.9790/7388-0254347

Akbar, S. (2016). Instrumen Perangkat Pembelajaran. Remaja Rosdakarya.

Alhinduan, S. R., Kurniawan, Y., \& Muliyani, R. (2016). Identifikasi Kuantitas Siswa Yang Miskonsepsi Pada Materi Listik Dinamis Menggunakan Three Tier-Test (TTT). JIPF (Jurnal Ilmu Pendidikan Fisika), 1(1), 29-31. https://doi.org/10.26737/jipf.v3i2.578

Annisa, R., Astuti, B., \& Mindyarto, B. N. (2019). Tes Diagnostik Four Tier untuk Identifikasi Pemahaman dan Miskonsepsi Siswa pada Materi Gerak Melingkar 
Beraturan. Jurnal Pendidikan Fisika Dan Keilmuan, 05(1), 25-32.

Anuardi, M. N. A. M., Shinohara, H., \& Yamazaki, A. K. (2016). A Pre-study of Background Color Effects on the Working Memory Area of the Brain. Procedia Computer Science, 96, 1172-1178. https://doi.org/10.1016/j.procs.2016.08.160

Aulia, S., Diana, N., \& Yuberti. (2018). Analisis Miskonsepsi Siswa Smp Pada Materi Fisika. Indonesia Journal of Science and Mathematics Education, 1(2), h. 155-161.

Banerjee, J., \& Bhattacharyya, M. (2011). Selection of the optimum font type and size interface for on screen continuous reading by young adults: an ergonomic approach. Journal of Human Ergology, 40(1-2), 47-62. https://doi.org/10.11183/jhe.40.47

Berman, E. A., \& Kuden, J. L. (2017). Scientific Literacy. In Agriculture to Zoology: Information Literacy in the Life Sciences (pp. 17-26). Elsevier Ltd. https://doi.org/10.1016/B978-0-08-100664-1.00002-8

Blackmore-Wright, S., Georgeson, M. A., \& Anderson, S. J. (2013). Enhanced text spacing improves reading performance in individuals with macular disease. PLoS ONE, 8(11), 1-12. https://doi.org/10.1371/journal.pone.0080325

Dogusoy, B., Cicek, F., \& Cagiltay, K. (2016). How Serif and Sans Serif Typefaces Influence Reading on Screen: An Eye Tracking Study. International Conference of Design, User Experience, and Usability, 1(July), 578-586. https://doi.org/10.1007/978-3-319-403557

Dragoş, V., \& Mih, V. (2015). Scientific Literacy in School. Procedia - Social and Behavioral Sciences, 209(July), 167-172. https://doi.org/10.1016/j.sbspro.2015.11.273

Fananta, M. R., Widjiasih, A. E., Setiawan, R., Hanifah, N., Miftahussururi, Nento, M. N., Akbari, Q. S., \& Ayomi, J. M. (2017). Materi Pendukung Literasi Sains (L. A. Mayani (ed.)). Kementerian Pendidikan dan Kebudayaan.

Fauzia, L. A., \& Madlazim. (2015). Pengaruh Penerapan Model Pembelajaran Diskusi Kelas Terhadap Penurunan Miskonsepsi Siswa Pada Pembelajaran Fisika SMA Materi IPBA. Jurnal Inovasi Pendidikan Fisika (JIPF), 04(01), 26-29.

Franken, G., Podlesek, A., \& Možina, K. (2015). Eye-tracking study of reading speed from LCD displays: Influence of type style and type size. Journal of Eye Movement Research, 8(1), 1-8. https://doi.org/10.16910/jemr.8.1.3

Gurel, D. K., Eryilmaz, A., \& McDermott, L. C. (2015). A review and comparison of diagnostic instruments to identify students' misconceptions in science. Eurasia Journal of Mathematics, Science and Technology Education, 11(5), 989-1008. https://doi.org/10.12973/eurasia.2015.1369a

Hasan, S., Bagayoko, D., \& Kelley, E. L. (1999). Misconceptions and the certainty of response index (CRI). Physics Education, 34(5), 294-299. https://doi.org/10.1088/0031-9120/34/5/304

Hidayatulloh, M., Wiryokusumo, I., \& Walujo, D. A. (2019). Remidiasi Miskonsepsi Siswa Pada Materi Listrik Dinamis Menggunakan Ebook Interaktif. Jurnal Pendidikan Fisika Dan Teknologi, 5(1), 10-15. http://research.nii.ac.jp/src/Chiba3Party.html

Hojjati, N., \& Muniandy, B. (2014). The Effects of Font Type and Spacing of Text for Online Readability and Performance. Contemporary Educational Techonology, 5(2), 161-174.

Hughes, L. E., \& Wilkins, A. J. (2002). Reading at a distance: Implications for the design of text in children's big books. British Journal of Educational Psychology, 72(2), 213226. https://doi.org/10.1348/000709902158856

Ilyas, A., \& Saeed, M. (2018). Exploring Teachers' Understanding about Misconceptions of Secondary Grade Chemistry Students. International Journal for Cross-Disciplinary $\begin{array}{llll}\text { Subjects in } & \text { Education, }\end{array}$ https://doi.org/10.20533/ijcdse.2042.6364.2018.0444

Keček, D., Zorko, A., Čerepinko, D., Tomiša, M., \& Ivančić Valenko, S. (2017). The impact of the text and background color on the screen reading experience. Technical Journal, $11(3), 78-82$. 
Kesuma, G. C., Diani, R., Hasanah, N., \& Fujiani, D. (2020). Blended Learning Model: Can It Reduce Students' Misconception in Physics? Journal of Physics: Conference Series, 1467(1). https://doi.org/10.1088/1742-6596/1467/1/012044

Kurniawan, D. T., \& Maryanti, S. (2018). Analysis of Math Teacher Candidates' Misconception on the Dynamic Electricity Concept. Scientiae Educatia, 7(1), 67. https://doi.org/10.24235/sc.educatia.v7i1.2481

Kurniawan, Y., Muliyani, R., \& Nassim, S. (2019). Digital Story Conceptual Change Oriented (DSCC) to Reduce Students' Misconceptions in Physics. Jurnal Ilmiah Pendidikan Fisika Al-Biruni, https://doi.org/10.24042/jipfalbiruni.v0i0.4596

Maison, M., Lestari, N., \& Widaningtyas, A. (2020). Identifikasi Miskonsepsi Siswa Pada Materi Usaha Dan Energi. Jurnal Penelitian Pendidikan IPA, 6(1), 32. https://doi.org/10.29303/jppipa.v6i1.314

Moret-Tatay, C., \& Perea, M. (2011). Do serifs provide an advantage in the recognition of written words? Journal of Cognitive Psychology, 23(5), 619-624. https://doi.org/10.1080/20445911.2011.546781

Neidorf, T., Arora, A., Erberber, E., Tsokodayi, Y., \& Mai, T. (2020). An Introduction to Student Misconceptions and Errors in Physics and Mathematics (pp. 1-10). https://doi.org/10.1007/978-3-030-30188-0_1

Nofiana, M., \& Julianto, T. (2018). Upaya Peningkatan Literasi Sains Siswa Melalui Pembelajaran Berbasis Keunggulan Lokal. 9(1), 24-35.

OECD. (2019). PISA 2018 Results. Combined Executive Summaries. Journal of Chemical Information and Modeling, 53(9), 1689-1699. www.oecd.org/about/publishing/corrigenda.htm.

Ozkan, G., \& Selcuk, G. S. (2015). Effect of Technology Enhanced Conceptual Change Texts on Students' Understanding of Buoyant Force. Universal Journal of Educational Research, 3(12), 981-988. https://doi.org/10.13189/ujer.2015.031205

Parwati, I., Makhrus, M., \& Gunada, I. W. (2019). Pengaruh Pendekatan Konflik Kognitif Terhadap Penurunan Miskonsepsi Peserta Didik pada Materi Usaha dan Energi. Pendidikan Fisika Dan Teknologi, 5(2), 278-286. http://repositorio.unan.edu.ni/2986/1/5624.pdf

Rosuli, N., Koto, I., \& Rohadi, N. (2019). Pembelajaran Remedial Terpadu Dengan Menerapkan Model Pembelajaran Generatif Untuk Mengubah Miskonsepsi Siswa Terhadap Konsep Usaha Dan Energi. Jurnal Kumparan Fisika, 2(3), 185-192. https://doi.org/10.33369/jkf.2.3.185-192

Samsudin, A., Liliawati, W., Sutrisno, A. D., Suhendi, E., \& Kaniawati, I. (2014). The Use of Computer Simulation in Cooperative Learning to Minimize Students' Misconceptions of Momentum and Impulse. Icaet, 72-74. https://doi.org/10.2991/icaet-14.2014.16

Saputri, D. F., \& Nurussaniah. (2015). Penyebab Miskonsepsi pada Optika Geometris. Prosiding Seminar Nasional Fisika, 4, 33-36.

Sharif, I., Wills, T. A., \& Sargent, J. D. (2010). Effect of Visual Media Use on School Performance: A Prospective Study. Journal of Adolescent Health, 46(1), 52-61. https://doi.org/10.1016/j.jadohealth.2009.05.012

Shin, S., Lee, J., \& Ha, M. (2017). Influence of Career Motivation on Science Learning in Korean High-School Students. 8223(5), 1517-1538. https://doi.org/10.12973/eurasia.2017.00683a

Simanek, D. E. (2016). Didaktikogenic Physics Misconceptions. https://www.lockhaven.edu/ dsimanek/scenario/miscon.htm

Suparno, P. (2013). Miskonsepsi \& Perubahan Konsep dalam Pendidikan Fisika. Gramedia Widiasarana.

Syuhendri, S. (2019). Student teachers' misconceptions about gravity. Journal of Physics: Conference Series, 1185(1). https://doi.org/10.1088/1742-6596/1185/1/012047 
Tarmizi, Halim, A., \& Khaldun, I. (2017). Penggunaan Metode Eksperimen Untuk Mengatasi Miskonsepsi Dan Meningkatkan Pemahaman Konsep Materi Rangkaian Listrik Di Sma Negeri 1 Jaya Kabupaten Aceh Jaya, Aceh. Jurnal Pendidikan Sains Indonesia (Indonesian Journal of Science Education), 5(1), 5-11.

Vieira, R. D., De Melo, V. F., Avraamidou, L., \& Lobato, J. A. (2017). Reconceptualizing scientific literacy: The role of students' epistemological profiles. Education Sciences, 7(2). https://doi.org/10.3390/educsci7020047

Vijaya, V. (2018). Impact of Visual media in Children's Literature: A Paradigm of Cognitive/Psycho- linguistic approach. International Journal of Linguistics, Literature and Translation, 1(4), 290403. https://doi.org/10.32996/ijllt.2018.1.4.16

Wandersee, J., Mintzes, J., \& Novak, J. (1994). Research on alternative conceptions in science. In Gabel (Ed.), Handbook of research on science teaching and learning. MacMillan.

Xia, T., Song, L., Wang, T. T., Tan, L., \& Mo, L. (2016). Exploring the effect of red and blue on cognitive task performances. Frontiers in Psychology, 7(MAY), 1-7. https://doi.org/10.3389/fpsyg.2016.00784

Yunita, \& Nana. (2020). Upaya Mengurangi Miskonsepsi pada Pembelajaran Fisika melalui Penerapan Model Creative Problem Solving Mahasiswa Program Studi Pendidikan Fisika, Universitas Siliwangi Dosen Program Studi Pendidikan Fisika, Universitas Siliwangi learning physics through. https://doi.org/10.31234/osf.io/9d5wv

Zajkov, O., Gegovska-Zajkova, S., \& Mitrevski, B. (2016). Textbook-Caused Misconceptions, Inconsistencies, and Experimental Safety Risks of a Grade 8 Physics Textbook. International Journal of Science and Mathematics Education, 15(5), 837852. https://doi.org/10.1007/s10763-016-9715-0

Zayyinah, Munawaroh, F., \& Rosidi, I. (2018). Identifikasi Miskonsepsi Siswa Smp Dengan Certainty of Response Index ( Cri ) Pada Konsep Suhu Dan Kalor. Science Education National Conference, 78-89.

Zulvita, Halim, A., \& Kasli, E. (2017). Identifikasi dan remediasi miskonsepsi konsep hukum newton dengan menggunakan metode eksperimen di man darussalam. Jurnal Ilmiah Mahasiswa (JIM) Pendidikan Fisika., 2(1), 128-134. 